\title{
Pemberdayaan Pemuda Karang Taruna Dan Ibu-Ibu Pkk di Kelurahan Pacar Kembang, Surabaya Junairiah $^{1}$, Tri Nurhariyati ${ }^{2}$, Listijani Suhargo ${ }^{3}$ \\ Departemen Biologi, Fakultas Sains dan Teknologi, Universitas Airlangga \\ alip.jun1@gmail.com
}

\begin{abstract}
Abstrak
Kelurahan Pacar Kembang terletak di wilayah Surabaya Timur. Permasalahan yang dihadapi oleh mitra adalah terdapat kampung yang kumuh dan belum tertata, juga pemuda karang taruna dan ibu-ibu PKK yang belum mempunyai kegiatan edukasi untuk dapat mewujudkan kampung yang bersih dan asri. Kegiatan ini bertujuan untuk mewujudkan kampung yang bersih, asri dan aman. Berdasarkan permasalahan tersebut di atas, maka permasalahan mitra yang harus segera ditangani adalah aspek lingkungan dan budidaya dengan memberikan pelatihan mural dan budidaya lidah buaya dilanjutkan dengan kegiatan praktek terhadap materi yang diberikan. Berdasarkan hasil evaluasi terhadap materi yang telah disampaikan menunjukkan bahwa rerata nilai pelatihan mural adalah 76 dan rerata nilai pelatihan budidaya lidah buaya adalah 82 . Hasil praktek pembuatan mural dan pelatihan budidaya berupa foto kegiatan.
\end{abstract}

Kata kunci: mural, lidah buaya

\section{PENDAHULUAN}

Surabaya merupakan salah satu kota metropolitan, banyak dipenuhi oleh gedung, hotel dan apartemen yang menjulang tinggi. Kehadiran ini di satu sisi memberikan dampak yang positif yaitu modernisasi, tetapi di sisi lain dikhawatirkan dengan berdirinya bangunan hotel, gedung maupun apartemen akan menjadikan kampung menjadi hilang dan kumuh Nursyahbani dan Pigawati, 2015). Kampung yang terdapat di perkotaan adalah sebuah perumahan atau pemukiman yang seperti kampung di pedesaan, tapi berada di perkotaan (Setiawan, 2005). Jika dilihat secara fisik sebagian kampung kota biasanya identik dengan ketidakteraturan hingga kondisi kumuh (Kelurahan Pacar Kembang merupakan kawasan yang terletak di Surabaya Timur. Kelurahan ini mempunyai area berupa tembok yang tidak terawat, juga pemuda karang taruna dan ibu-ibu PKK yang belum mempunyai kegiatan edukasi untuk dapat mewujudkan kampung yang bersih, asri dan sehat.

Terwujudnya Smart City ini harus didukung pula dengan adanya perkampungan yang cerdas (Komaruljannah, 2019). Oleh sebab itu untuk mewujudkannya adalah dengan dilakukan pembenahan kampung kumuh dan pemanfaatan lingkungan hidup secara produktif. Salah satu upaya yang dapat dilakukan adalah dengan memberikan pelatihan mural (lukisan di tembok) untuk menghilangkan kesan kumuh dan juga upaya penanaman tanaman yaitu lidah buaya. Diharapkan dengan terwujudnya kampung smart city dapat dijadikan sebagai destinasi wisata.

- Mitra dalam Program Kemitraan Masyarakat (PKM) ini adalah pemuda karang taruna dan ibu ibu PKK yang ada di Kelurahan Pacar Kembang. Permasalahan yang dihadapi oleh mitra adalah adanya kampung yang kumuh dan belum tertata, juga pemuda karang taruna

$$
\text { Ekonomi, Sosial dan Budaya }
$$

1194 
dan ibu-ibu PKK yang belum mempunyai kegiatan edukasi untuk dapat mewujudkan kampung yang bersih dan asri.

\section{METODE}

Metode pelaksanaan kegiatan meliputi pemberian pelatihan dan evaluasi pelaksanaan kegiatan. Materi pelatihan terdiri atas:

Pelatihan pembuatan lukisan di dinding (mural dan praktek langsung melukis di dinding). Peserta dalam hal ini pemuda karang taruna diberi pelatihan bagaimana cara membuat lukisan di dinding dengan berbagai tema.

Pelatihan penanaman dan pemeliharaan tanaman lidah buaya

Budidaya lidah buaya

Bahan yang diperlukan adalah lidah buaya, polybag, media tanam, sprayer, pupuk. Sama halnya seperti langkah-langkah menanam, langkah pertama yang harus kita lakukan adalah menyiapkan polybag sebagai tempat untuk menanam tanaman lidah buaya (Ismiyati et al., 2017).

Media yang digunakan adalah tanah kering, atau tanah campuran ini bisa berupa pasir dan pupuk kandang. Jika kedua bahan tersebut sudah tercampur, maka tanah campuran tersebut siap dimasukkan ke dalam polybag.Selain campuran tanah dengan pupuk kandang, juga bisa menggunakan campuran berupa pasir, batu apung, dan perlit. Untuk campuran media tanam ini pada umumnya digunakan oleh orang rumahan karena untuk mempercantik media tanam.

Cara menanam lidah buaya ini sama halnya dengan cara menanam tanaman lainnya, yaitu sebagai berikut langkah-langkahnya: mengambil anakan, cara menanam dengan menancapkan, dengan catatan tidak terlalu dalam atau dangkal, serta yang perlu dicatat lidak suka air.

Evaluasi Pelaksanaan Kegiatan

Setelah penyampaian materi pelatihan pembuatan mural dan budidaya lidah buaya diadakan evaluasi atau postest. Selain itu peserta pelatihan meunjukkan hasil prakteknya berupa mural dan hasil budidaya lidah buaya.

\section{PEMBAHASAN}

1.Pelatihan Pembuatan Mural

Peserta pelatihan pembuatan mural adalah pemuda karang taruna. Kegiatan ini karena dilaksanakan pada masa pandemi Covid maka dilakukan secara online. Materi disampaikan melalui video tentang pembuatan mural, selain itu materi pelatihan disampaikan melalui whatsapp. Kegiatan pelatihan ini dilaksanakan pada tanggal 8 Agustus 2020. Pada pelatihan ini materi yang diberikan adalah pembuatan sketsa, pewarnaan, pendetailan gambar, dan finishing. Untuk mengevaluasi sejauh mana pengetahuan para peserta terhadap mural ini dengan memberikan postest. Pemberian postest diberikan secara online melalui google form. Hasil dari postest menunjukkan bahwa rerata nilai peserta adalah 76 (Gambar 1). Para peserta pelatihan juga praktek membuat berbagai sketsa berupa tari remo merupakan tanda ucapan selamat datang, produk kuliner makanan dan minuman yang menunjukkan bahwa produk yang dihasilkan oleh warga kampung, jembatan Suramadu merupakan lambang kota Surabaya, ikon bonek, pemandangan, gunungan wayang dan lain-lain (Gambar 2). Mural merupakan salah satu gambar yang menggunakan dinding tembok sebagai media. Mural ini dapat digunakan sebagai media interaksi seni ( Gazali, 2017). Selain seni juga dapat digunakan sebagai media edukasi bagi masyarakat. Di Kecamatan Bojongsoang, Bandung juga dibuat mural dengan tema kebudayaan Bojongsoang sehingga dapat menjadi media edukasi bagi masyarakat Bojongsoang sendiri (Althaf et al., 2017). Mural juga dapat dikatakan sebagai bentuk komunikasi visual. Di Jalan Ireda Yogyakarta mural tidak hanya di media dinding tembok tetapi juga di jalan raya (Iswandi, 2016). 


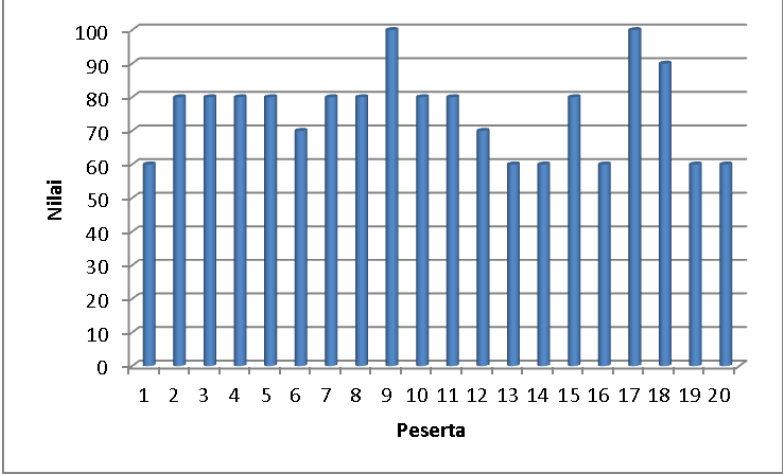

Gambar 1. Hasil postest peserta pelatihan mural
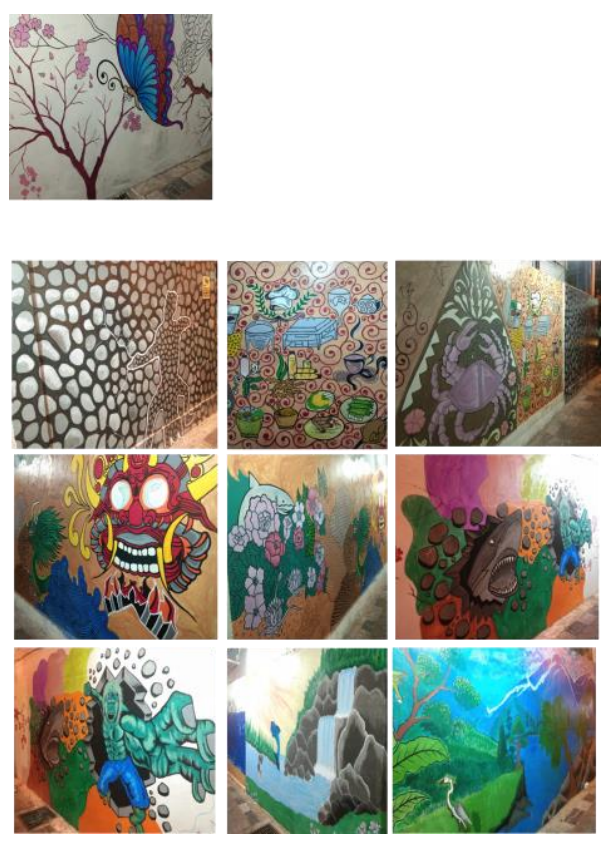

Gambar 2. Hasil pembuatan mural Pelatihan Budidaya Lidah Buaya

Untuk pelatihan budidaya lidah buaya, sasaran mitranya adalah ibu-ibu PKK. Kegiatan pengabdian ini karena dilaksanakan dalam suasana pandemi Covid, maka untuk pelaksanaan dilakukan secara online. Materi pelatihan disampaikan melalui whatsapp. Kegiatan ini dilaksanakan pada tanggal 9 Agustus 2020. Materi yang diberikan pada pelatihan ini adalah persiapan pot dan media tanam, pembibitan lidah buaya, cara penanaman, pemeliharaan, panen dan pasca panen. Untuk teknis pelaksanaannya masingmasing peserta mendapat satu buah pot lidah buaya, kemudian dipelihara dan ditunjukkan hasilnya setelah penanaman selama 2 bulan. Seperti halnya pelatihan mural peserta pelatihan lidah buaya juga dievaluasi. Evaluasi dilaksanakan secara online melalui google form. Hasil evaluasi menunjukkan bahwa rerata nilai postest adalah 82 (Gambar 3). Bibit lidah buaya dan penyerahan bibit kepada ibuibu PKK terdapat pada gambar 4.

Pelatihan lidah buaya juga dilakukan di Tebo Selatan, Mulyorejo, Sukun, Malang. Pelatihan ini bertujuan untuk mendeskripsikan minat masyarakat terhadap manfaat lidah buaya dengan pengisian angket atau kuesioner (Noordia dan Nurita, 2018). Pelatihan budidaya lidah buaya dan pengolahannya diadakan di kota Depok. Hasil pelatihan menunjukkan bahwa peserta yaitu ibu-ibu menyenangi kegiatan ini karena dapat membantu kewirausahaan (Ismiyati et al., 2017).

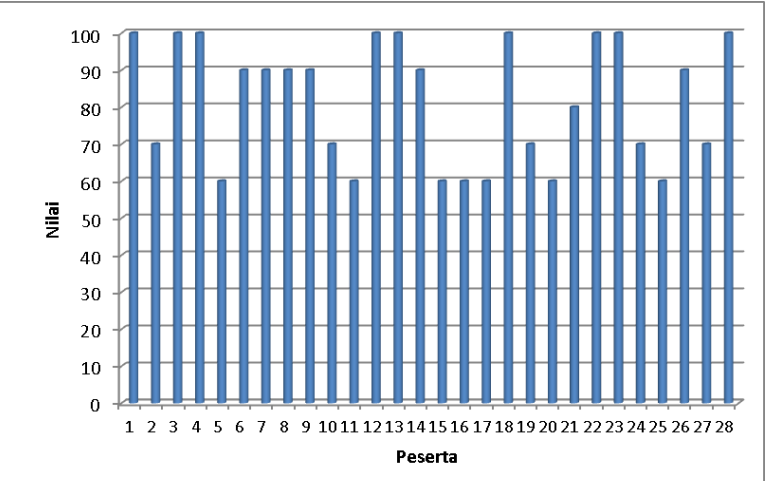

Gambar 3. Hasil postest peserta pelatihan budidaya lidah buaya

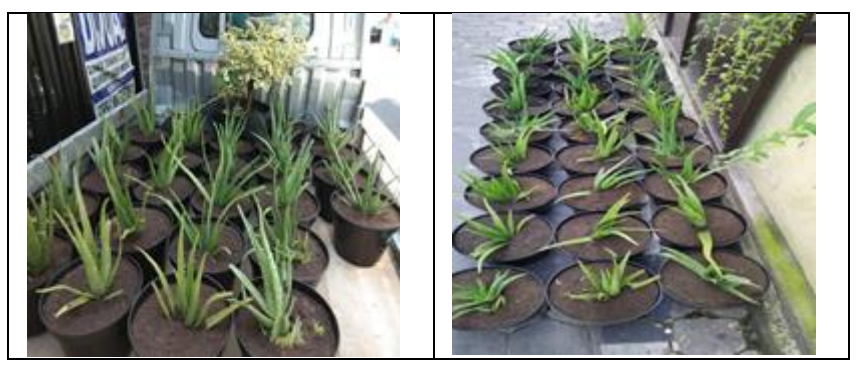




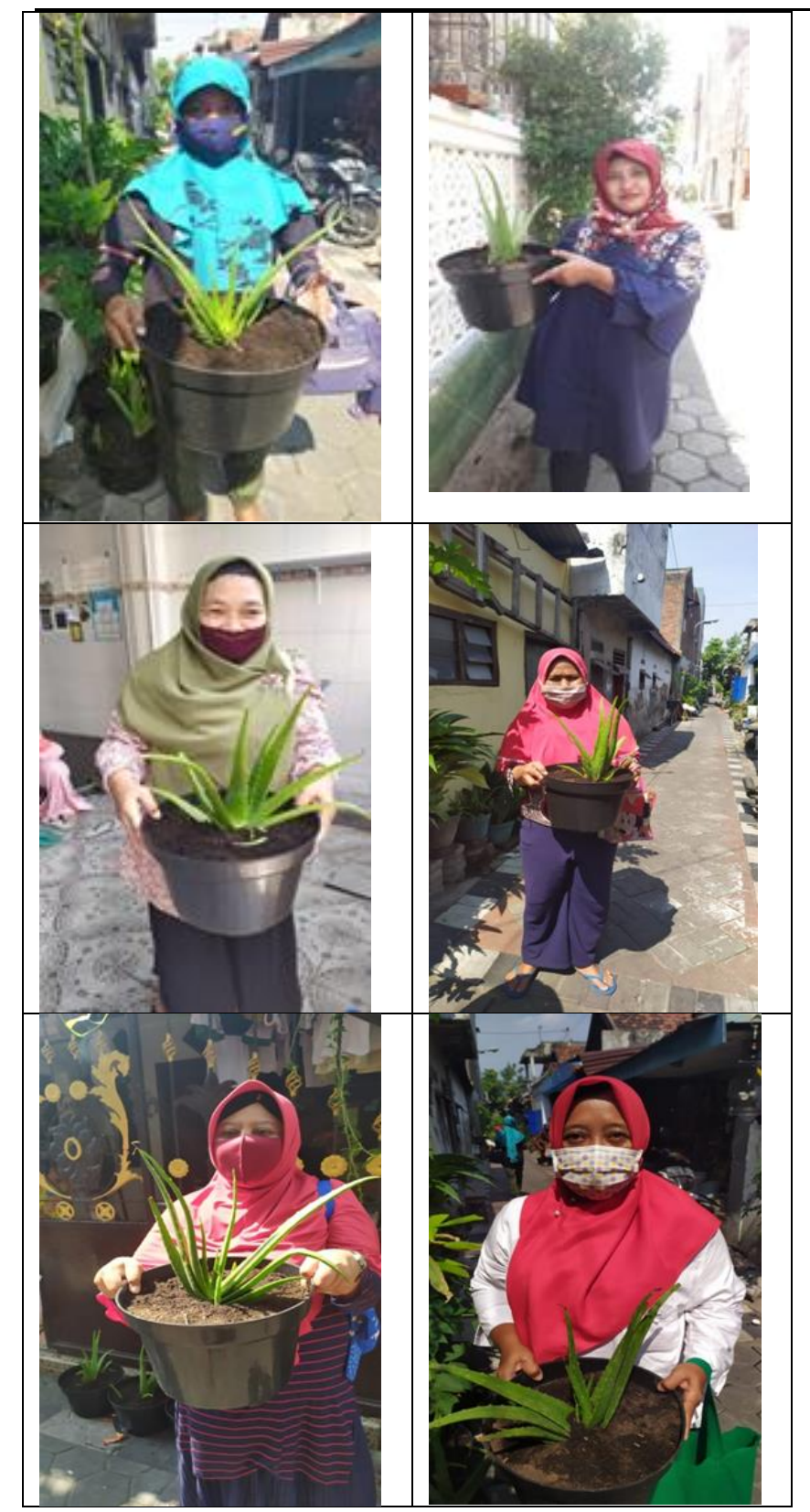

Gambar 4. Bibit lidah buaya dan penyerahan bibit kepada ibu-ibu PKK

Dampak dari kegiatan pengabdian masyarakat adalah warga khususnya pemuda karang taruna dan ibu-ibu PKK mendapatkan pengetahuan tentang pembuatan mural (lukisan di dinding) dan cara budidaya lidah buaya.

KESIMPULAN
Pada kegiatan pengabdian masyarakat ini peserta mendapat pengetahuan tentang pembuatan mural dan cara budidaya lidah buaya.

\section{UCAPAN TERIMA KASIH}

Kegiatan ini terlaksana dengan bantuan dana RKAT Fakultas Sains dan Teknologi, Universitas Airlangga, dengan SK Rektor Unair Nomor 532/UN3/2020.

\section{REFERENSI}

Althaf, M.A. 2017. Mural Sebagai Media Edukasi Mengenai Kebudayaan Kecamatan Bojongsoang Dengan Memanfaatkan Ruang Dua Dimensi Yang Terbengkalai. EProceeding of Art and Design Vol 4. No 3.

Gazali, M. 2017. Seni Mural Ruang Publik dalam Konteks Konservasi. Jurnal Imajinasi Vol XI No 1.

Ismiyati I, Hendrawati I, dan Nugraha RA. 2017. Pelatihan Budidaya dan Pengolahan Aloe vera Menjadi Bahan Tambahan Makanan dan Lotion di Aisyiyah Kota Depok. Prosiding SnaPP.

Iswandi, H. 2016. Seni Mural Sebagai Unsur Politik Dalam Kehidupan Sosial. Jurnal Ilmu Desain dan Budaya. Vol 3. No. 1.

Komaruljannah E. 2019. Kampung Cerdas untuk Kota Cerdas. https://www.kompasiana.com/erlinakomaruljan nah2919/5b0a073dcf01b4607d76e893/kampun g-cerdas-untuk-kota-cerdas-smart-city-disurabaya

Noordia, A. dan Nurita, T. 2018. Pelatihan Lidah Buaya Masyarakat Tebo Selatan Kelurahan Mulyorejo. Jurnal ABDI Vol. 3 No. 2.

Nursyahbani R dan Pigawati B. 2015. Kajian Karakteristik Kawasan Pemukiman Kumuh di Kampung Kota. Jurnal Teknik PWK. Vol. 4 No. 2: 267-281.

Setiawan B. 2005. Kampung Kota dan Kota Kampung. UGM Press. Yogyakarta.

Sobirin. 2001. Distribusi Pemukiman dan Prasarana Kota: Studi Kasus Dinamika 
Pembangunan Kota di Indonesia. Universitas Indonesia. Jakarta. 